\title{
Phytoremediation of Phosphorous and Ammonia with Eichhornia crassipes and Azolla pinnata in Waste Waters from Estero de San Miguel Mendiola Manila Philippines
}

\author{
$L$ Acero \\ Professor and Chairperson, Department of Natural Sciences, College of Arts and Sciences San Beda University Manila, \\ Philippines
}

\begin{abstract}
Wastewater treatment and removal of pollutants by phytoremediation, remain a major concern of the $21^{\text {th }}$ century. This study is focused on the phytoremediation study in Philippine setting, specifically in one of the tributaries of Pasig river-the Estero de San Miguel. It determined the $\mathrm{pH}$, Ammonia and Phosphorous before, $7^{\text {th }}$ and $14^{\text {th }}$ day of phytoremediation with the use of $A$. pinnata and E. crassipes. Twelve improvised water ponds/troughs, 3 ponds per treatment were used for 14 days. T- control (only wastewater), T1 for A. pinnata + wastewater, T2 for E. crassipes + wastewater and T3 for A. pinnata E. crassipes + wastewater. Potential hydrogen, Ammonia-N mg/L, phosphorous mg/L were analyzed before, on the $7^{\text {th }}$ and $14^{\text {th }}$ day of the study. Data gathered was analyzed using ANOVA and Fisher Least Significant Difference test as post hoc test. Result revealed that T1 (A. pinnata) lowered the $\mathrm{pH}$ and ammonia-N (mg/L) of wastewaters from Estero de San Miguel. T3 (combination of $A$. pinnata $+E$. crassipes) has significantly lowered the Phosphorous level of the wastewaters. Thus both aquatic macrophytes can be used as phytoremediation agents in the said Estero.
\end{abstract}

\section{Introduction}

Urban industrialization is always coupled by environmental pollution particularly bodies of water, turning previously biocompatible lakes and rivers and rivulletes. There are many methods of removing pollutants from wastewater but phytoremediation is gaining popular. It has been observed that phytoremediation of wastewater using the floating plant system is a predominant method which is economic to construct, requires little maintenance and increase the biodiversity [1]. Phytoremediation strategies, based on the abilities of aquatic plants to recycle nutrients, offer an attractive solution for the bioremediation of water pollution, and represents one of the most globally researched issues. The subsequent application of the biomass from the remediation for the production of fuels and petrochemicals offers an ecologically friendly and cost-effective solution for water pollution problems and production of value-added products [2].Phosphorous in wastewaters came from decomposition of organic matter from human waste and from detergents and soaps which is one of the many pollutants in wastewaters.
Phosphorous in the form of phosphate plays an important role in metabolic activities of the plant such as; photosynthesis, respiration, energy storage and transfer, cell division, cell enlargement. Ammonia on the other hand, gives wastewater a pungent odour due to action taken by most bacteria in its metabolism and is mostly preferred by pond plants than nitrate. Aquatic plants can use ammonia directly. Together with sugars aquatic plants can metabolize even in dark reaction.

Estero de San Miguel is located in Manila, Philippines. It is one of the 47 major tributaries of Pasig river, and has a sub-cathcment area of 259261.2 square meters [3]. A study on the analyses of physicochemical parameters of the esteros - turbidity, temperature, salinity, EC, $\mathrm{pH}$, DO, BOD, COD,TKN, TP, chl-a, and oil and greaseshowed the estero waters fall under Class D water quality criterion. TKN and TP values indicated hypertrophic conditions AT all stations. Low chl-a values were indicative of stressful conditions to the primary producers. Nineteen phytoplankton genera Cyanophyta (3 spp), Chlorophyta (9 $\mathrm{spp})$ and Bacillariophyta (7 spp) thrived in the esteros [4].

Azolla pinnata with a preferred common name, mosquito fern, under the domain: Eukaryota, Kingdom: 
Plantae, Phylum: Pteridophyta, Class: Filicopsida, Family: Azollaceae; is small aquatic plants. It is 1.5-2.5 $\mathrm{cm}$ long, with a $+/$ - straight main axis with pinnately arranged side branches, progressively longer towards the base, thus roughly triangular in shape; the basal branches themselves becoming pinnate and eventually fragmenting as the main axis decomposes to form new plants. Roots have fine lateral rootlets, giving a feathery appearance in the water. Leaves minute, 1-2 $\mathrm{mm}$ long, overlapping in two ranks, upper lobe green, brownish green or reddish, lower lobe translucent brown; minute, short, pillae, +/cylindrical unicellular hairs often present on the upper lobes. When fertile, round sporocarps 1-1.5 mm wide can be seen on the underside at the bases of the side branches. The leaves often have a maroon-red tinge and the water can appear to be covered by red velvet from the distance. $A$. pinnata is often applied to rice paddies as a nitrogen fertilizer and weed suppressant [5]. Azolla pinnata has many uses. It can be used as bio-fertlizer, feed for poultry and fish [6].The plant is an aquatic fern of stagnant water. It can spread rapidly and has the ability to survive on moist soil in and around rivers, ditches, and ponds; it also occurs in Papyrus swamps, on sandbanks, in sluggish rivers and in neglected paddy fields. The occurrence of a vigorously growing population of azolla in a farm dam generally indicates high nutrient levels in the water. Azolla can survive within a water $\mathrm{pH}$ range of 3.5 to 10 , but optimum growth occurs in the $\mathrm{pH}$ range of 4.5 to 7 and temperature range of $18^{\circ} \mathrm{C}$ to $26^{\circ} \mathrm{C}$. [7].. Under optimum conditions, azolla's growth spreads across the dam surface until it covers the surface of the water in a dense cover. Azolla can double its leaf area in seven days if conditions of high nutrient levels and water temperatures persist [8].\Azolla does not thrive under adverse conditions: extreme cold or heat. But it can be preserved even under such adverse conditions in very slow moving water bodies such as streams, canals, sewage channels, small ponds and tanks and unused wells. They are known as inoculum banks. The optimum temperature for azolla ranges between $15-35^{\circ} \mathrm{C}$ [9].

Water hyacinth (Eichhornia crassipes), is a native of Brazil and is introduced to and is naturalized in many tropical countries like Philippines [10]. All along the Pasig River in the Philippines, water hyacinths can be found almost year-round; they sometimes cover a complete section of the river so that no water is visible. Obviously, it has acclimated very favorably, but no one cares about controlling it and using its merits for the environment [11].Water hyacinth can be recommended as costless, efficient and friendly environmental process for waste water treatment [12]. The presence of phosphorus and nitrogen in excess amounts could lead to the eutrophication of water sources, which may also create environmental conditions that favour the growth of toxin-producing cyanobacteria. Chronic exposure to some of such toxins produced by these organisms can cause a host of other diseases [13]. Objective of the study. This study determined the chemical characteristic $(\mathrm{pH}$, Phosphorous and ammonia-N) of wastewaters from
Estero de San Miguel, Mendiola Manila Philippines before, $7^{\text {th }}$ and $14^{\text {th }}$ day use of azolla pinnata and Eichhornia crassipes as phytoremediation agents.

\section{Methodology}

\section{A. Materials}

Plant materials used in this study were $A$. pinnata and $E$. crassipes which were collected from Azolla Farm and water pond in La Union, Pangasinan, Philippines (figure 1)

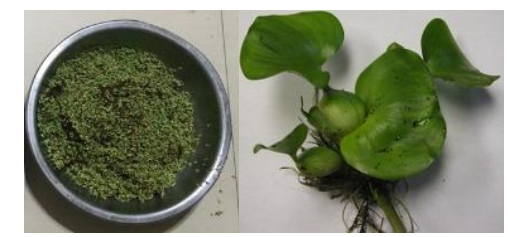

Fig. 1. Samples of A. pinnata (left) and E. crassipes (right).

Other materials used are; measuring glass, plastic strainer, weighing scale, Whatman paper no. 1, digital $\mathrm{pH}$ meter, 12 improvised plastic containers as water troughs/ ponds. (see figures 2-a, 2-b, and 2-c).

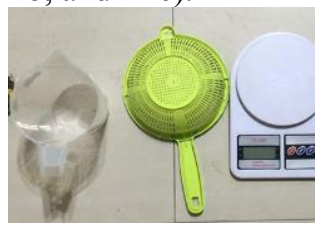

Fig. 2-a. measuring glass, plastic strainer and weighing scale.
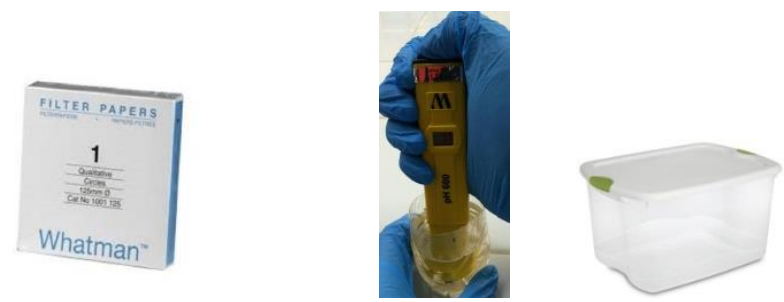

Fig. 2-b. Whatmann paper no. 1, digital pH. 2-c. Improvised plastic trough/ pond.

\section{B.Methods}

A study on phytoremediation of wastewaters [14] served as a guide in the conduct of this research. Wastewaters was collected from Estero de San Miguel Mendiola Manila Philippines and brought to the experimental site in plastic containers.

The aquatic plants selected for phytoremediation were $A$ pinnata and $E$. crassipes. It was collected freshly from natural pond at Azolla Farm in La Union, Pangasinan Philippines. These plants were cleaned properly to remove dirt and dust under tap water and stabilize in laboratory conditions for 2-3 days to normalize their growth. Complete randomized design with four treatments and three samples was used to conduct the 
experiment as shown in the experimental set-up (figure 3).

The laboratory conditions were maintained uniform throughout the experimental period. This study is limited to 3 main chemical characteristics of wastewater samples (pre and post treatments) such as $\mathrm{pH}$, phosphorous and ammonia. These characteristics were determined by using standard methods, such as digital $\mathrm{pH}$ meter for its potential hydrogen. The Phosphorous and ammonia content were determined by American Public Health Association (APHA), the American Water Works Association (AWWA) methods. The data were analyzed statistically by using ANOVA and Fisher Least Significant Difference test as post hoc test.

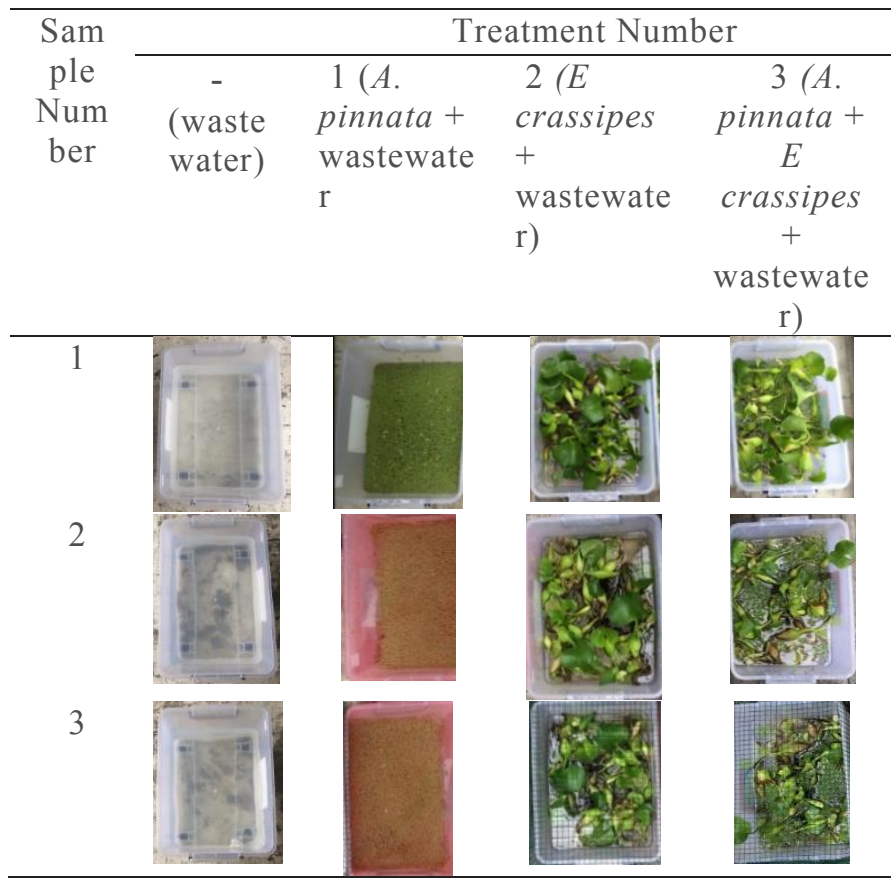

Fig.3. Experimental lay-out

E. crassipes about 8-10 inches long and $A$. pinnata were used as experimental plants The weight of Azolla pinnata was recorded after keeping them on a filter paper to remove excess water. An initial analysis of main $\mathrm{pH}$, phosphorous $\mathrm{mg} / \mathrm{l}$ and ammonia-N mg/l was done. Newly collected wastewater samples were delivered to Water Analysis laboratory in clean tighten glass containers (before and $7^{\text {th }}$ and $14^{\text {th }}$ day of experimentation), for the determination of phosphorous and ammonia content. Plants were contained in plastic ponds/troughs having capacity of 33 liters wastewater following the treatments as follows; T-: control no aquatic plant.T1:400 grams of $A$. pinnata in wastewater from Estero de San Miguel; T2: 20 pieces E. crassipes in wastewater from Estero de San Miguel; and T3: 200 grams A. pinnata $+10 E$. crassipes in wastewater from Estero de San Miguel

\section{Results}

\subsection{Initial Potential Hydrogen (pH) of wastewater per treatment per sample}

Table 1 posited the initial potential hydrogen of waste water samples per treatment. Since wastewaters came from one source, (Estero de San Miguel in Mendiola Manila Philippines), the $\mathrm{pH}$ of waste waters, before the study is 6.9. The $\mathrm{pH}$ of waste water samples are below the neutral $\mathrm{pH}$ of 7 which indicate that aquatic plants used can thrive in the water. Azolla can survive within a $\mathrm{pH}$ range of 3.5 to 10 [15]. E. crasippes (water hyacinth) plants survived in a $\mathrm{pH}$ range of 4.0 to 8.0. Both alkaline $\mathrm{pH}$ (above 8.0) and highly acidic $\mathrm{pH}$ (below 4.0) had inhibitory effect on the growth of plants [16].Potential hydrogen $(\mathrm{pH})$ varies depending on the geology of the river catchment, on river flow, and on wastewater discharges but is generally in the range $6-9$ [17].

\subsection{Initial Phosphorous (mg/L) of wastewater per treatment per sample}

In freshwater, phosphorous the natural background levels of total phosphorus are generally less than $0.03 \mathrm{mg} / \mathrm{L}$. The natural levels of phosphate usually range from 0.005 to $0.05 \mathrm{mg} /$ [18]. Table 2 shows that the initial phosphorous level of wastewaters, are beyond the level of freshwaters $(1 \mathrm{mg} / \mathrm{l})$ thus, wastewater is euthrophic. Euthrophic water source has $0.03-0.1 \mathrm{mg} / \mathrm{l}$ of total phosphorous [19].

Phosphorus (P) is the most critical and limiting input for Azolla rice cultivation Azolla absorbs $\mathrm{P}$ from the floodwater and makes it available to the plant [20].

Table 1. Initial potential hydrogen $(\mathrm{pH})$ per treatment per sample

\begin{tabular}{lllll}
\hline Sample & \multicolumn{4}{c}{ Treatment } \\
& - & 1 & 2 & 3 \\
\hline 1 & 6.9 & 6.9 & 6.9 & 6.9 \\
2 & 6.9 & 6.9 & 6.9 & 6.9 \\
3 & 6.9 & 6.9 & 6.9 & 6.9 \\
Total & 20.7 & 20.7 & 20.7 & 20.7 \\
Mean & 6.9 & 6.9 & 6.9 & 6.9 \\
\hline
\end{tabular}

Table 2. Initial phosphorous content per treatment per sample

\begin{tabular}{lcccc}
\hline Sample & \multicolumn{4}{c}{ Treatment } \\
& - & 1 & 2 & 3 \\
\hline 1 & 1 & 1 & 1 & 1 \\
2 & 1 & 1 & 1 & 1 \\
3 & 1 & 1 & 1 & 1 \\
Total & 3 & 3 & 3 & 3 \\
Mean & 1 & 1 & 1 & 1 \\
\hline
\end{tabular}




\subsection{Initial Ammonia (mg./L) of wastewater per treastment per sample}

Table 3 displays the initial Ammonia content of wasters which is $8 \mathrm{mg} / \mathrm{l}$. Natural (unpolluted) waters contain relatively small amounts of ammonia, usually less than $0.02 \mathrm{mg} / \mathrm{l}$ as $\mathrm{N}$ [21]. With the above initial ammonia and phosphorous content of the wastewaters from Estero de San Miguel, it shows that it can favor the growth of Azolla pinnata and E. crassipes

The levels of available nitrogen and phosphorous are the most important factors limiting in growth. The halfsaturation co-efficients for water hyacinths grown under constant conditions have been found to be from $0.05-1$ $\mathrm{mg} / \mathrm{l}$ for total nitrogen and from $0.02-0.1 \mathrm{mg} / \mathrm{l}$ for phosphates. Growth quickly tails off below the lower limits [22].

Table 3. Initial ammonia (mg/L) content per treatment per sample

\begin{tabular}{lllcl}
\hline Sample & \multicolumn{3}{c}{ Treatment } \\
& - & 1 & 2 & 3 \\
\hline 1 & 8 & 8 & 8 & 8 \\
2 & 8 & 8 & 8 & 8 \\
3 & 8 & 8 & 8 & 8 \\
Total & 24 & 24 & 24 & 24 \\
Mean & 8 & 8 & 8 & 8 \\
\hline
\end{tabular}

\subsection{Mean Potential hydrogen of wastewaters, before, $7^{\text {th }}$ and $14^{\text {th }}$ day of experimentation}

Table 4 shows the mean $\mathrm{pH}$ from initial, $7^{\text {th }}$ and $14^{\text {th }}$ day of experimentation. Treatment 1 had the highest mean $\mathrm{pH}$ (7.36), followed by T3 (7.13), T2 (7.01) and T- (6.9) respectively. The result revealed that the ponds/troughs with $A$. pinnata had increased the $\mathrm{pH}$ from 6.9 to 7.36 which is nearest to neutral. Analysis of Variance (ANOVA) demonstrate that there is significant difference ( $\mathrm{p}$ value is lower than 5\% level of significance) among the treatment means in 14 days of experiment in terms of $\mathrm{pH}$. Fisher Least significant difference calculated that significant difference exist between T1vs.T2 and as indicated by different superscripts in the mentioned treatment.

The result indicates that $A$. pinnata can increase the $\mathrm{pH}$ of wastewaters from Estero de San Miguel. The $\mathrm{pH}$ after phytoremediation using $A$. pinnata is 7.36. Potential hydrogen rises with photosynthetic activities of azolla plant. A study on phytoremediation using E. crassipes reported that there was no much change for $\mathrm{pH}$. The $\mathrm{pH}$ value was found to be between 6 and 8 [23].

Table 4. Mean potential hydrogen, before, $7^{\text {th }}$ and $14^{\text {th }}$ day of experimentation

\begin{tabular}{lllll}
\hline Days & \multicolumn{4}{c}{ Treatment } \\
& - & 1 & 2 & 3 \\
\hline initial & 6.9 & 6.9 & 6.9 & 6.9 \\
7th & 6.9 & 7.3 & 7 & 7.1 \\
14th & 6.9 & 7.9 & 7.3 & 7.4 \\
Total & 20.7 & 22.1 & 21.2 & 21.4 \\
Mean & $6.9^{\text {acd }}$ & $7.36^{\text {b }}$ & $7.01^{\mathrm{c}}$ & $7.13^{\text {d }}$ \\
\hline
\end{tabular}

\begin{tabular}{lcrrrrr}
\multicolumn{8}{c}{ ANOVA } \\
\hline \multicolumn{1}{c}{$S V$} & $S S$ & $d f$ & $M S$ & $F$ & $\begin{array}{c}P \text { value } \\
\text { crit }\end{array}$ \\
\hline Rows & 0.461 & 2 & 0.230 & $5.36^{*}$ & 0.04 & 5.14 \\
Columns & 0.336 & 3 & 0.112 & 2.60 & 0.14 & 4.75 \\
Error & 0.258 & 6 & 0.043 & & & \\
Total & 1.056 & 11 & & & & \\
\hline
\end{tabular}

Legend: * significant at 5\% level of significance

\subsection{Mean phosphorous level ( $\mathrm{mg} / \mathrm{L})$ of wastewater before, $7^{\text {th }}$ and $14^{\text {th }}$ day of experimentation}

The mean phosphorous in $\mathrm{mg} / \mathrm{L}$ of treatments is displayed in table 5. Lowest phosphorus level was obtained in T3 (.31), followed by T1 (.783), T2 (.83) and T- remained 1. ANOVA showed significant difference and Fisher LSD revealed significant difference in pairs of T- vs T3, T1 vs. T3 and T2 vs T3 as shown in the difference of superscripts in treatment means. The result further implies that a combination of $A$. pinnata ad E. crassipes in wastewaters significantly lowered the Phosphorous level of wastewaters in Estero de San Miguel Mendiola Manila Philippines. Azolla plants showed substantial Premoval efficiency from P-eutrophicated solutions. Several studies showed that both macrophytes can lower the phosphorous level in wastewaters. Water hyacinth showed its ability to survive in high concentration of nutrients. Significant removals of ammonia and phosphorus, respectively was obtained using the water hyacinth plants. Use of water hyacinths can help reduce eutrophication effects in receiving streams and also improve its water quality [24]. The Aquatic fern Azolla was used to treat waste water. Because of the capability of $\mathrm{N}$ fixation by Azolla, the efficient removal of phosphorus would be expected even after $\mathrm{N}$ is consumed [25].

Table 5. Mean phosphorous (mg/L) level, before, $7^{\text {th }}$ and $14^{\text {th }}$ day of experimentation

\begin{tabular}{lcccc}
\hline Days & \multicolumn{4}{c}{ Treatment } \\
& - & 1 & 2 & 3 \\
\hline initial & 1 & 1 & 1 & 1 \\
7 th & 1 & 0.96 & 0.99 & 0.62 \\
& & & & \\
14th & 1 & 0.39 & 0.5 & 0.32 \\
Total & 3 & 2.35 & 2.49 & 0.94 \\
Mean & $1^{\text {ab }}$ & $.783^{\text {ad }}$ & $83^{\text {bd }}$ & $.31^{\mathrm{c}}$ \\
\hline
\end{tabular}

ANOVA

\begin{tabular}{lcrrrrrr}
\hline \multicolumn{1}{c}{$S V$} & $S S$ & $d f$ & $M S$ & \multicolumn{1}{c}{$F$} & P-value & \multirow{2}{*}{ F crit } \\
\cline { 1 - 6 } Rows & 0.433 & 2 & 0.216 & $6.803^{*}$ & 0.028 & 5.14 \\
Columns & 0.189 & 3 & 0.063 & 1.982 & 0.22 & 4.75 \\
Error & 0.191 & 6 & 0.031 & & &
\end{tabular}




\subsection{Mean ammonia-N Level $(\mathrm{mg} / \mathrm{L})$ of wastewater before, $7^{\text {th }}$ and $14^{\text {th }}$ day of experimentation}

Table 6 reveals the mean ammonia-N level $(\mathrm{mg} / \mathrm{L})$ on the initial, $7^{\text {th }}$ and $14^{\text {th }}$ day of experimentation. Treatment 1 had the lowest mean of $5.03 \mathrm{mg} / \mathrm{L}$, followed by 2 (5.32), T3 (5.75) and T- (8) respectively. The result revealed that the ponds/troughs with $A$. pinnata had lowered the ammonia-N (mg/l) from 8 to 5.03. Analysis of Variance (ANOVA) demonstrate that there is significant difference ( $\mathrm{p}$ value is lower than 5\% level of significance) among the treatment means on the $7^{\text {th }}$ and $14^{\text {th }}$ day of experimentation .Fisher Least significant difference calculated that significant difference exist between $\mathrm{T}$ vs.T1 and T- vs. T2 as indicated by different superscripts in the mentioned treatment.

The result indicates that $A$. pinnata can lower the ammonia-N (mg/L) of wastewaters from Estero de San Miguel, in 14 days of experimentation much faster than $E$. crassipes and the combination of $E$. crassipes and $A$. pinnata. Azolla can grow well in effluents from wastewater stabilization ponds despite the high ammonium content of the medium [26]

Table 6. Mean ammonia-N (mg/L) content, before, $7^{\text {th }}$ and $14^{\text {th }}$ day of experimentation

\begin{tabular}{cllll}
\hline Days & \multicolumn{2}{l}{ Treatment } & & \\
& - & 1 & 2 & 3 \\
\hline initial & 8 & 8 & 8 & 8 \\
7 th & 8 & 4.85 & 5.23 & 5.97 \\
14th & 8 & 2.26 & 2.74 & 3.28 \\
Total & 24 & 15.11 & 15.97 & 17.25 \\
Mean & $8^{\text {a }}$ & $5.03^{\text {bde }}$ & $5.32^{\text {cdf }}$ & $5.75^{\text {aef }}$ \\
\hline
\end{tabular}

\begin{tabular}{rcrllll}
\multicolumn{8}{c}{ ANOVA } \\
\hline S.V & SS & df & MS & F & P-value & F crit \\
\hline Rows & 30.89 & 2 & 15.44 & $8.66^{*}$ & 0.017 & 5.14 \\
Columns & 16.33 & 3 & 5.44 & 3.05 & 0.11 & 4.75 \\
Error & 10.69 & 6 & 1.78 & & & \\
Total & 57.92 & 11 & & & & \\
\hline
\end{tabular}

Legend: * significant at $5 \%$ level of significance

\section{Conclusion}

Eutrophication of wastewaters can be minimized by the used of indigenous plants like A. pinnata and $E$. crassipes. Result of this study implied that $A$. pinnata increased the $\mathrm{pH}$ of wastewaters from Estero de San Miguel and lowered the ammonia $(\mathrm{mg} / \mathrm{L})$ content in 14 days. The combination of $A$. pinnata and E. crassipes lowered the phosphorous $(\mathrm{mg} / \mathrm{L})$ content of wastewater. Thus, both aquatic macrophytes can be used as potential phytoremediation agents. Based from the result of this study several phytoremediation studies and projects can be proposed in order to control ammonia and phosphorous level in wastewaters. Since this study was conducted on improvised waterpond, a study on-pond can be done to determine the growth response of the plants in lotic environment. Proper spacing, and growth management of both aquatic plants, in a given area to avoid $\mathrm{O} 2$ depletion in wastewaters is also recommended. A study on the use of both aquatic plants as organic fertilizer in other aquatic plants can be undertaken.

\section{References}

1. Piyush G, Surendra R and Mahindrakar M 2011 Treatment of Water Using Water Hyacinth, Water Lettuce and Vetiver Grass - A Review Resources and Environment. 2(5) pp 202-215 DOI: $10.5923 /$ j.re.20120205.04

2. Muradov N, Taha M, Miranda A, Kadali K, Gujar A, Rochfort S, Stevenson T, Ball S, and Mouradov A 2014 .Dual application of duckweed and azolla. Biotechnology for Biofuels. 7(30) pp 117.

3. Oñate L 2015 Pasig River Rehabilation and the Urban Poor:A Case Study of Informal Seetlers' Fight to Stay in Manila.Masters thesis in Global Studies. University of Gotthemburg

4. Orozco P and Zafaralla 2012 Biophysico-Chemical and Socioeconomic Study of Two Major Manila Esteros. Biology Education for Social and Sustainable Development. Sense Rotterdam

5. Croft J 2015. The aquatic Pteridophytes of New Guinea. Australian National Herbarium, Centre for Plant BiodiversityResearch. Australian National Botanic Gardens and Centre for

Australian National Biodiversity Research, Canberra.

6. Watanabe I 1986 Summary report of the Azolla programme of theInternational Network on Soil fertility and fertilizer evaluation for rice,"Azolla utilization.. International Rice Research Institute, Manila. 1(1) pp 187-205.

7. Gupta A and Beentje H 2017 Azolla pinnata. The IUCN Red List of Threatened Species. http://dx.doi.org/10.2305/IUCN.UK.20171.RLTS.T168790A84276316.en

8. Walker T 2002 Azolla Growth in Farm Dams. Agriculture Victoria.

9. Jagran M 2015 Azolla Numerous Uses: From Farm Till Dairy. Krishi Jagran Media Group.

10. Mahmood Q, Zheng P, Siddiqi M, Islam E, Azim M, and Y. Hayat 2005 Anatomical

studies on water hyacinth (Eichhornia crassipes (mart.) solms) under the influence of textile wastewater. Journal of Zhejiang University. 6(10) pp 991-998 
11. Park D 2008 .Water Hyacinth: Exceptionally Beneficial Pesty Plant. Retrieved July 2, 2018 from

http://ecop.pbworks.com/w/page/18520928/Water\%2 0Hyacinth\%20Pollution $\% 20$

Control\%20Properties\%200708

12. Saleh H 2016 Biological Remediation of Hazardous Pollutants Using Water Hyacinth $-A$

Review. Journal of Biotechnology Research 2(11) pp: 80-91.

13. Akpor O, Othinoyi D, Olaolu T, and J.B. Alderiye. 2014 Pollutants in wastewater effluents: impacts and remediation processes .International Journal of Environmental Research and Earth Science.3(3) pp 050-059.

14. Dar S, Kumawat D, Singh N and K.A. Wani. 2011 Sewage Treatment Potential of Water Hyacinth (Eichhornia crassipes) Research Journal of Environmental Sciences. 5 (4) pp 377-385

15. Subudhi B and P. K. Singh 1979 Effect of macronutrients and $\mathrm{pH}$ on the growth nitrogen

fixation and soluble sugar content of water fern Azolla pinnata. Biologia plantarum

21(1).pp.66-

0/.https://doi.org/10.1007/BF02888721

16. A.S. El-Gendy, N. Biswas and JK. Bewtra. (2004). Growth of water hyacinth in municipal

landfill leachate with different $\mathrm{pH}$. Environmental Technology.25(7)pp.833-840

17. US Environmental Protection Agency: Environmental Services Branch (ESB) Laboratory.

River Water Monitoring-Information on water quality parameters. Retrieved August 9, 2018

from:

https://www.epa.ie/pubs/reports/water/waterqua/iwq molou/App\%207.pdf.

18. Science Labs 2016 Black Earth Creek and Limnology Minifacts andAnalysis. Retrieved August 2, 2018 from:http://osse.ssec.wisc.edu/curriculum/earth/Mini fact2_Phosphorus.pdf

19. Arora A and Saxena S Centre for Conservation of Blue Green Algae, Indian Agricultural

Research Institute (IARI), New Delhi 110012, India.

20. Eutrophication. Retrieved July 10, 2018 from: http://www.open.edu/openlearn/ocw/mod /oucontent/view.php?printable=1\&id=2317

21. Information on water quality parameters. Retrieved August 5, 2018 from:

https://www.epa.ie/pubs/reports/water/waterqua /iwqmolou/App\%207.pdf

22. Floating aquatic macrophytes - Water hyacinth. Retrieved July 15, 2018 from htpp://www.fao.org/docrep/02/i1141e/i1141e04.pdf

22. Neethu V and M Chinnamma 2017 Phytoremediation effect in dairy waste water and domestic

waste water using constructed wetlands of Azolla pinnata International Journal of Research in
Sustainalble Environmenta and Technology 4(5).pp.9-17

23. Lissy M and G. Madhu.2011. Removal of Heavy Metals from Waste Water Using Water Hyacinth. ACEEE Int. J. on Transportation and Urban Development, 1(1) pp.1-5

24.Kutty S, Ngatenah S, Isa M and Malakahmad A 2009 Nutrients Removal from Municipal Wastewater Treatment Plant Effluent using Eichhornia Crassipes. World Academy of Science, Engineering and Technology. 60 (1) pp. 826-831

25. Shiomi N \& Kitoh S 2008 Nutrient absorption capacity of Azolla from waste water and use of Azolla plant as biomass. Journal of Plant Nutrition, 10(1).pp 1663-1670

26. Costaa M, Santosb M, Carrapic, oc F, and Pereira L. 2009 Azolla-Anabaena's behaviour in. urban wastewater and artificial media - Influence of combined nitrogen Water Research : A Journal of International Water Association. water research 43(1)pp. 3743-3750 